Article

\title{
A Simple Route to Produce Highly Efficient Porous Carbons Recycled from Tea Waste for High-Performance Symmetric Supercapacitor Electrodes
}

\author{
Xiaoxiao Qu ${ }^{1}$, Weiwei Kang ${ }^{2}$, Changwei Lai ${ }^{3}$, Chuanxiang Zhang ${ }^{2, *}$ and Suck Won Hong ${ }^{1, *(D)}$ \\ 1 Department of Cogno-Mechatronics Engineering, Pusan National University, Busan 46241, Korea; \\ m18339169838@163.com \\ 2 College of Chemistry and Chemical Engineering, Henan Polytechnic University, Jiaozuo 454000, China; \\ weiweikangwell@163.com \\ 3 School of Materials Science and Engineering, Anyang Institute of Technology, Anyang 455000, China; \\ laichangwei0229@163.com \\ * Correspondence: zcx223@hpu.edu.cn (C.Z.); swhong@pusan.ac.kr (S.W.H.)
}

check for updates

Citation: Qu, X.; Kang, W.; Lai, C.; Zhang, C.; Hong, S.W. A Simple Route to Produce Highly Efficient Porous Carbons Recycled from Tea Waste for High-Performance Symmetric Supercapacitor Electrodes. Molecules 2022, 27, 791. https:// doi.org/10.3390/molecules27030791

Academic Editors: Xiuyi Lin and Zhenglong $\mathrm{Xu}$

Received: 11 December 2021

Accepted: 19 January 2022

Published: 25 January 2022

Publisher's Note: MDPI stays neutral with regard to jurisdictional claims in published maps and institutional affiliations.

Copyright: () 2022 by the authors Licensee MDPI, Basel, Switzerland. This article is an open access article distributed under the terms and conditions of the Creative Commons Attribution (CC BY) license (https:// creativecommons.org/licenses/by/ $4.0 /)$.

\begin{abstract}
High-performance porous carbons derived from tea waste were prepared by hydrothermal treatment, combined together with $\mathrm{KOH}$ activation. The heat-treatment-processed materials possess an abundant hierarchical structure, with a large specific surface of $2235 \mathrm{~m}^{2} \mathrm{~g}^{-1}$ and wettingcomplemental hydrophilicity for electrolytes. In a two-electrode system, the porous carbon electrodes' built-in supercapacitor exhibited a high specific capacitance of $256 \mathrm{~F} \mathrm{~g}^{-1}$ at $0.05 \mathrm{~A} \mathrm{~g}^{-1}$, an excellent capacitance retention of $95.4 \%$ after 10,000 cycles, and a low leakage current of $0.014 \mathrm{~mA}$. In our work, the collective results present that the precursor crafted from the tea waste can be a promising strategy to prepare valuable electrodes for high-performance supercapacitors, which offers a practical strategy to recycle biowastes into manufactured materials in energy storage applications.
\end{abstract}

Keywords: tea waste; hydrothermal treatment; porous carbon; supercapacitor

\section{Introduction}

Supercapacitors, including electric double-layer capacitors (EDLCs) and pseudocapacitors, have garnered continuous attention as an efficient energy storage system due to their higher power density, superior rate performance, longer cycle life, and a wider range of applications, compared with other energy storage systems [1-8]. In the material systems, electrodes play an important role in determining electrochemical performance [9-13]. Activated carbons (ACs) have been used as a conventional material for EDLC electrodes because of their intrinsic characteristic properties, such as high specific surface area, developed pore structure, and suitable surface chemical state [14-16]. Over the past years, much attention has been focused on transforming natural waste to worth-added ACs, such as carton [17], longan shell [18], sesame husk [19], lemon peel [20], walnut shells [21], lignocellulose [22], and palm [23]. As a result of the previous studies, it was found that there is great significance and research value in discovering low-cost and high-performance electrode materials by utilizing biowaste.

In China, the world's largest tea-producing country [24], most of the tea waste is discarded as useless material, which leads to environmental pollution and resource waste. Therefore, there is a timely demand to search for an effective strategy for the efficient recycling of tea waste. In this context, it has been widely investigated to use tea waste as an electrode material associated with the high carbon content, pore structure, and large surface area, especially for supercapacitor applications. For example, the rod-like, porous carbon, with a specific surface area of $1610 \mathrm{~m}^{2} \mathrm{~g}^{-1}$, was synthesized through the precarbonization and simple $\mathrm{KOH}$ activation at $700^{\circ} \mathrm{C}$, using tea waste as a raw material [25]. 
The mesoporous graphitic carbon, prepared by $\mathrm{KOH}$ activation, from the green tea waste (i.e., carbon precursor) represented the specific capacitance of $162 \mathrm{~F} \mathrm{~g}^{-1}$ at $0.5 \mathrm{~A} \mathrm{~g}^{-1}$ [26]. The activated carbon derived from tea waste was fabricated by the $\mathrm{ZnCl}_{2}$ activation with a surface area of $1308 \mathrm{~m}^{2} \mathrm{~g}^{-1}$ and a total pore volume of $0.812 \mathrm{~cm}^{3} \mathrm{~g}^{-1}$ [27]. Additionally, the activated carbons produced from tea waste were prepared by chemical activation using $\mathrm{K}_{2} \mathrm{CO}_{3}$ and $\mathrm{H}_{3} \mathrm{PO}_{4}$ as activation agents, in which the highest specific capacitance of AC-K and AC-H electrodes are $203 \mathrm{~F} \mathrm{~g}^{-1}$ and $123 \mathrm{~F} \mathrm{~g}^{-1}$ at $1.5 \mathrm{~mA} \mathrm{~cm}^{2}$, respectively [28]. These previous reports indicated that tea waste could be utilized as excellent electrode materials for high-performance supercapacitors with a large surface area from the intrinsic porous structure.

Due to the advantages of low energy consumption and ease of processing [29-31], the hydrothermal method is currently one of the most attractive techniques for energy storage materials. Here, we developed a simple method to produce high-quality porous carbon materials derived from tea waste by using hydrothermal treatment, combined together with $\mathrm{KOH}$ activation, which is a well-established approach in the preparation of carbon-based electrode materials. For the recycling process of tea waste, we systematically surveyed the sufficient effect of the $\mathrm{KOH}$ agent in a delicately tailored manner to optimize the performance of the electrodes at a sufficient level of the porosity that entailed the highly beneficial structured surfaces for improved electrochemical performances in supercapacitors. In this study, we present an efficient and cost-effective approach that utilizes biowaste as a functional material for supercapacitor electrodes.

\section{Materials and Methods}

\subsection{Materials}

As a raw material, the typical tea waste (Xinyang Maojian, Xinyang, China) was ground into a powder (200 mesh). The $\mathrm{KOH}$ agent was purchased from Tianjin Damao Reagent Factory without any further purification.

\subsection{Preparation of ACs}

The two-step process, consisting of hydrothermal carbonization and chemical activation, was used to prepare the activated carbons. First, $40 \mathrm{~g}$ of tea waste was hydrothermally carbonized for $10 \mathrm{~h}$ at $180^{\circ} \mathrm{C}$ with $400 \mathrm{~mL}$ of deionized water (DIW) in a $500 \mathrm{~mL}$ of stainlesssteel autoclave, and the precipitates were gathered and dried. Next, the precursor and $\mathrm{KOH}$ with the mass ratios of 1:2, 1:3, and 1:4 were mixed with the DIW and dried for $10 \mathrm{~h}$, and then the stock was transferred into a horizontal tube furnace at $800^{\circ} \mathrm{C}$ for $1 \mathrm{~h}$ with $\mathrm{N}_{2}$ to achieve the activation. Finally, the as-prepared materials were soaked in $1 \mathrm{M} \mathrm{HCl}$, washed with DIW, and dried to obtain the ACs. According to the different ratios of the precursor and $\mathrm{KOH}$, the tea-waste-based activated carbon was named TAC, TAC2, TAC3, or TAC4, in which the TAC was the sample after the hydrothermal process without the $\mathrm{KOH}$.

\subsection{Characterization}

The morphology of the as-prepared samples was observed by SEM (JSM-6390LV, JEOL) and TEM (JEOLJEM-2100, JEOL). Specific surface area and pore size distribution were calculated using the Brunauer-Emmett-Teller (BET) and density-functional theory (DFT) methods. The crystal structure of the as-prepared samples was collected by XRD (Bruker, Birrika, MS, USA). The bonding states and elemental composition were measured by FT-IR spectroscopy (Nicolet Nexus 470) and XPS (PHI5300/ESCA, Lafayette, LA, USA).

\subsection{Electrochemical Measurements}

The electrochemical performances of the as-prepared materials were evaluated in a $3 \mathrm{M} \mathrm{KOH}$ aqueous electrolyte by using the symmetrical two-electrode system. The asprepared samples ( $85 \mathrm{wt} . \%)$, carbon black (10 wt.\%), and polytetrafluoroethylene (5 wt.\%) were mixed to prepare the electrode materials. CV, GCD, cycling performance, and leakage 
currents were tested on an electrochemical workstation (CSCT, Arbin, TX, USA). The single specific capacitance $(\mathrm{F} / \mathrm{g})$ was calculated with the following equation [32],

$$
C_{m}=\frac{2 I \times \Delta t}{\Delta V \times m}
$$

where $I(\mathrm{~A}), \Delta t(\mathrm{~s}), m(\mathrm{~g})$, and $\Delta V(\mathrm{~V})$ are the response current, the discharge time, the mass loading of the active materials in a single electrode, and the working potential, respectively.

\section{Results and Discussion}

The schematic of the preparation process of the tea-waste-based activated carbon materials is shown in Figure 1. The morphology of the as-prepared samples was measured by SEM and TEM in Figure 2. The SEM image of TAC (Figure 2a) presents the relatively rough surface, which can facilitate the penetration of the $\mathrm{KOH}$ activation agent, contributing to the formation of the pores [33]. As shown in Figure 2b, the TAC2 starts to appear with some pores on the surface. Following the continuous increase in the $\mathrm{KOH}$ amount (i.e., TAC3), the randomly interconnected three-dimensional structure with different pore sizes is developed in Figure 2c. When the ratio increases to 4, the TAC4 exhibits a highly etched morphology with the fragmented structure (Figure 2d). These results suggested that the employed optimum $\mathrm{KOH}$ had an important effect on the morphology of the activated carbons. It is worth noting that the abundant pores of TAC3 may act as potential reservoirs to store the electrolyte and supply continuous energy. Moreover, the hierarchical structure can shorten the passway of the charge transfer and decrease the resistance of the ion diffusion to expect enhanced electrochemical performances. As presented in Figure 2e-g, TEM images of the TAC3 present a porous morphological configuration, which is in accordance with the result of the SEM images. Meanwhile, the high-resolution TEM image (Figure $2 \mathrm{~h}$ ) also reveals the amorphous nanostructures with a lower degree of ordering in the ACs $[34,35]$.

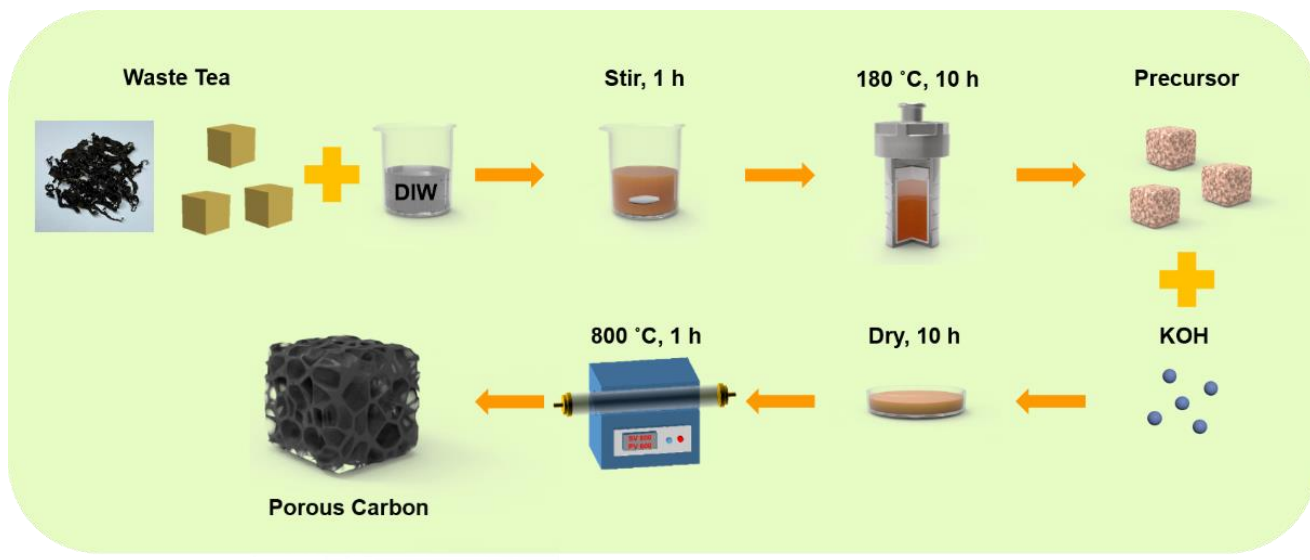

Figure 1. Schematic of the sequential preparation process of the tea-waste-based activated carbon materials.

The nitrogen adsorption/desorption was tested to investigate the surface areas and the related pore structures. As shown in Figure $3 a$, the isotherm of the TAC basically coincides with the line of $Y=0$, and the adsorption amount was low in the structure, revealing the pore structure of the hydrothermal carbon was extremely underdeveloped. The isotherms of TAC2 and TAC3 are identified as I type, according to the IUPAC classification, in which the adsorption capacity increases rapidly with the increase in relative pressure when $P / P_{0}<0.1$; the adsorption plateaus appear at a relative pressure between $0.1-0.4$, indicating TAC2 and TAC 3 are predominantly microporous structures. The adsorption/desorption isotherm of TAC4 exhibits a combined I/IV type [36,37], with a steep $\mathrm{N}_{2}$ uptake at $P / P_{0}<0.1$ and a typical $\mathrm{H} 4$ hysteresis loop at $P / P_{0}>0.4$, manifesting that TAC4 possesses micropores and mesopores. The pore size distribution curves are shown in Figure $3 b$, in which the pore 
sizes of TAC2, TAC3, and TAC4 were mainly distributed in $\sim 1-5 \mathrm{~nm}$ and included both micropores $(\sim 1-2 \mathrm{~nm})$ and mesopores $(\sim 2-5 \mathrm{~nm})$. The pore size distribution of TAC (the inset of Figure $3 b$ ) consists of limited micropores and mesopores; the corresponding textural characteristics are summarized in Table 1. The TAC displays extremely low porosity with a specific surface area of $5 \mathrm{~m}^{2} \mathrm{~g}^{-1}$ and a pore volume of $0.034 \mathrm{~cm}^{3} \mathrm{~g}^{-1}$, which are similar to those of products derived from other types of biowaste $[32,38,39]$. By increasing the $\mathrm{KOH}$ agent, the specific surface area notably increases from $2143 \mathrm{~m}^{2} \mathrm{~g}^{-1}$ to $2235 \mathrm{~m}^{2} \mathrm{~g}^{-1}$ and then decreases to $2206 \mathrm{~m}^{2} \mathrm{~g}^{-1}$. In addition, mesoporosity gradually increases from $20.7 \%$ to $63.2 \%$ with the increased level of the activating $\mathrm{KOH}$ amount. This is because the $\mathrm{KOH}$ activation is divided into two parts: micropore formation (pore creation) and micropore expansion (pore expansion) [40]. While micropore features were induced upon $\mathrm{K}$ evaporation following infiltration, the existing micropores were expanded into mesopores by the gasification of carbonate $\left(\mathrm{CO}_{3}{ }^{2-}\right)$ in $\mathrm{K}_{2} \mathrm{CO}_{3}$ [41]. However, when the ratio of $\mathrm{KOH} / \mathrm{TAC}$ increases to 3, the micropores enlarge into mesopores, owing to excessive $\mathrm{KOH}$ etching [42]. The $\mathrm{KOH}$ activation mechanism is shown in the following equation [26,41]:

$$
6 \mathrm{KOH}+2 \mathrm{C} \rightarrow 2 \mathrm{~K}+3 \mathrm{H}_{2}+2 \mathrm{~K}_{2} \mathrm{CO}_{3}
$$
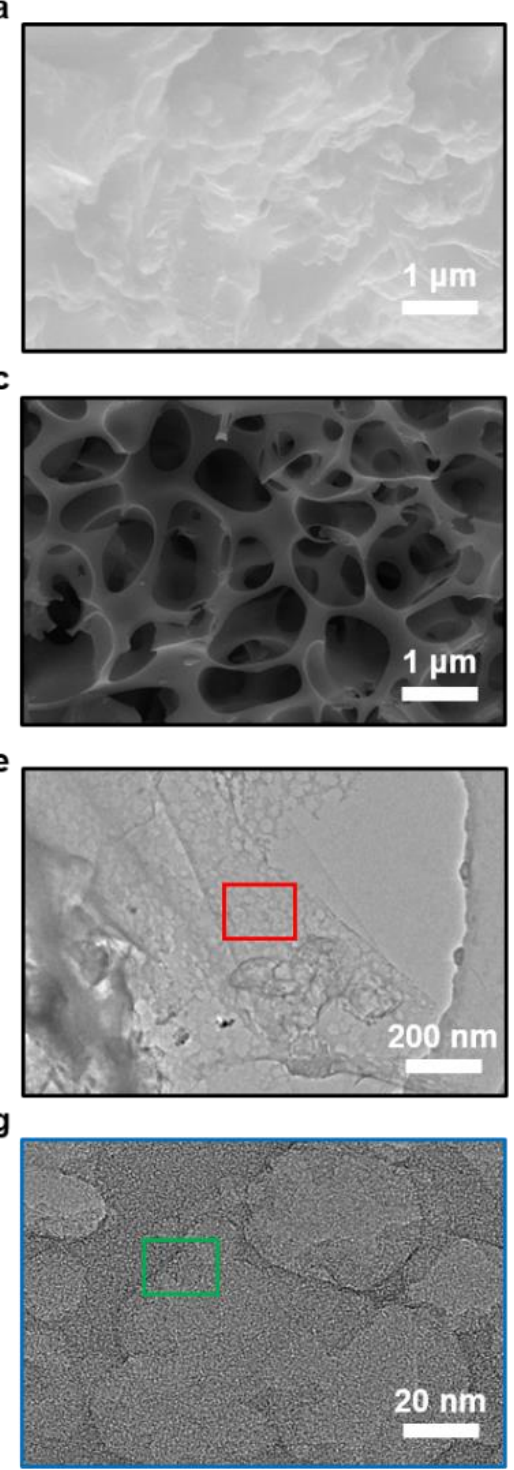

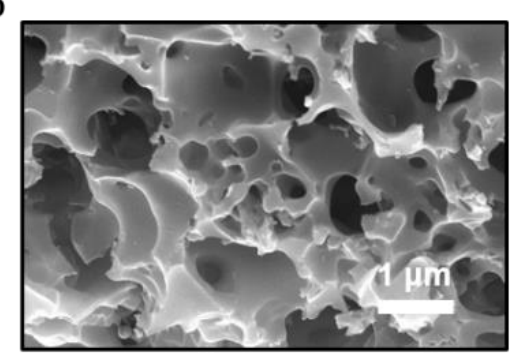

d

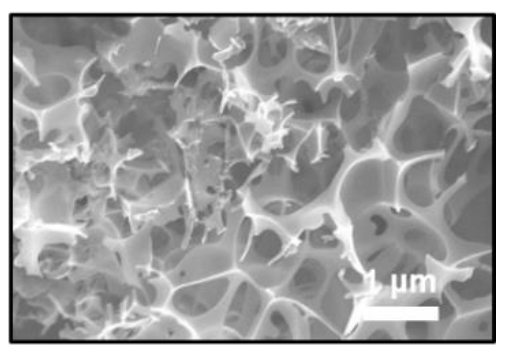

$\mathbf{f}$

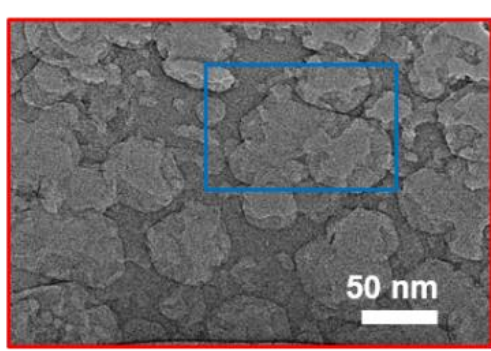

h

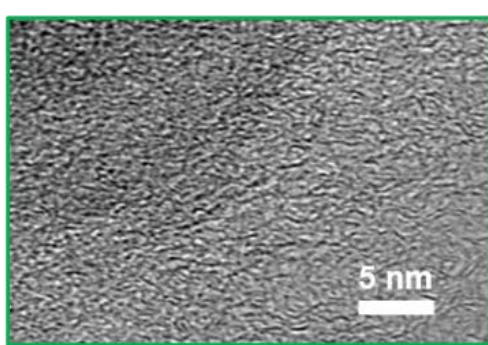

Figure 2. SEM images of the porous carbon electrodes: (a) TAC.; (b) TAC2; (c) TAC3; (d) TAC4; (e-h) TEM images of TAC3. 

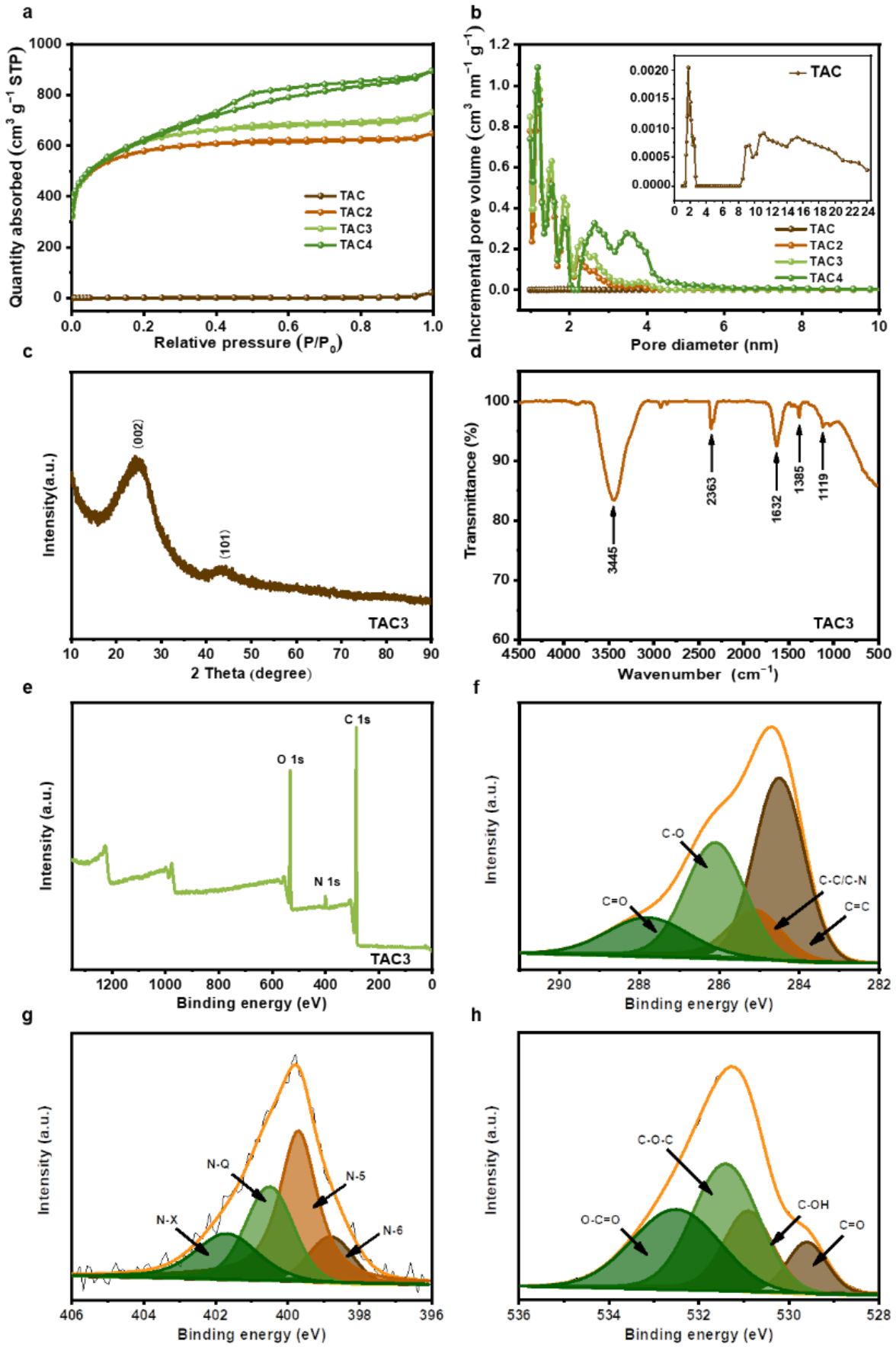

Figure 3. $\mathrm{N}_{2}$ adsorption-desorption isotherms (a) and pore size distributions (b) of tea-waste-based activated carbons, XRD pattern (c), FT-IR analysis (d), XPS survey spectra (e), and high-resolution C 1s (f), N 1s (g), and O 1s spectra (h) of TAC3.

Table 1. Textural characteristics of the activated carbons.

\begin{tabular}{cccccc}
\hline Samples & $\begin{array}{c}S_{\text {BET }} \\
\mathbf{m}^{\mathbf{2}} \mathbf{g}^{-\mathbf{1}}\end{array}$ & $\begin{array}{c}V_{\text {total }} \\
\mathbf{c m}^{\mathbf{3}} \mathbf{g}^{-\mathbf{1}}\end{array}$ & $\begin{array}{c}V_{\text {mic }} \\
\mathbf{c m}^{\mathbf{3}} \mathbf{g}^{-\mathbf{1}}\end{array}$ & $\begin{array}{c}V_{\text {mes }} \\
\mathbf{c m}^{\mathbf{3}} \mathbf{g}^{\mathbf{- 1}}\end{array}$ & $\begin{array}{c}V_{\text {mes }} / V_{\text {total }} \\
\mathbf{\%}\end{array}$ \\
\hline TAC & 5 & 0.034 & 0.002 & 0.032 & 94.1 \\
TAC2 & 2143 & 1.006 & 0.798 & 0.208 & 20.7 \\
TAC3 & 2235 & 1.135 & 0.796 & 0.339 & 29.9 \\
TAC4 & 2206 & 1.387 & 0.511 & 0.836 & 63.2 \\
\hline
\end{tabular}


The large specific surface area with porous structures provides abundant active sites to accelerate the electron transfer and the ion diffusion that drives an improved electrochemical performance of the activated carbons. The microstructure of the TAC3 was readily measured by XRD. As a result of the XRD pattern in Figure 3c, the broad diffraction peak, at approximately $2 \theta=25^{\circ}$, and the weak diffraction peak, centered at $43^{\circ}$, corresponded to the (002) crystal planes of the turbostratic carbon and the (101) diffraction of graphitic carbon, respectively, indicating the TAC3 belongs to the amorphous carbon with the disordered nature and low degree of graphitization $[43,44]$, which is in agreement with the TEM results. Subsequently, the surface chemistries were characterized by FT-IR in the range of 4500-500 $\mathrm{cm}^{-1}$, as shown in Figure $3 \mathrm{~d}$. The broadband, at $3445 \mathrm{~cm}^{-1}$, and the weak peak, at $2363 \mathrm{~cm}^{-1}$, can be attributed to an $\mathrm{O}-\mathrm{H}$ stretching and hydrogen-bonded or ionized compound structure [45]. The peaks at $1632 \mathrm{~cm}^{-1}$ are associated with the $\mathrm{C}=\mathrm{C} / \mathrm{C}=\mathrm{O}$ stretching vibration [46,47]. The peaks at approximately 1385 and $1119 \mathrm{~cm}^{-1}$ indicate the vibration modes of the $\mathrm{C}-\mathrm{N}$ and $\mathrm{C}-\mathrm{O}-\mathrm{C}$ groups $[48,49]$. These results revealed that the as-prepared carbons possessed a variety of surface functional groups, which were further evaluated by XPS spectroscopy. The XPS spectrum shows that TAC3 is mainly composed of carbon, nitrogen, and oxygen elements (Figure 3e). As presented in Figure 3f, the C 1 s spectrum is divided into four peaks by Gaussian fitting, located at 284.5, 285.1, 286.1, and $287.8 \mathrm{eV}$, which are ascribed to the bonds of $\mathrm{C}=\mathrm{C}, \mathrm{C}-\mathrm{C} / \mathrm{C}-\mathrm{N}, \mathrm{C}-\mathrm{O}$, and $\mathrm{C}=\mathrm{O}$, respectively [17]. The high-resolution $\mathrm{N}$ 1s spectrum is deconvoluted into four peaks at 398.8, $399.7,400.5$, and $401.7 \mathrm{eV}$, are assigned to pyridinic- $\mathrm{N}$ (N-6), pyridone-N or pyrrolic- $\mathrm{N}$ (N-5), quaternary-N (N-Q), and pyridine N-oxide (N-X) as illustrated in Figure 3g [50,51]. The $\mathrm{O}$ 1s XPS spectrum is fitted into four peaks at approximately 531.3, 532.5, 533.2, and $533.9 \mathrm{eV}$, corresponding to the oxygen-containing groups $\mathrm{C}=\mathrm{O}, \mathrm{C}-\mathrm{O}, \mathrm{C}-\mathrm{O}-\mathrm{C}$, and $\mathrm{O}-\mathrm{C}=\mathrm{O}$, respectively, as presented in Figure $3 \mathrm{~h}[17,52]$. The above set of results suggests that TAC3 has various $\mathrm{O}$-containing and $\mathrm{N}$-containing groups on the surface. Importantly, these functional groups can effectively improve the hydrophilicity and wettability of activated carbon, thus making the surface accessible to aqueous electrolytes and capable of excellent electrochemical performances [53-55].

The as-prepared samples were tested as electrodes for the symmetric supercapacitors in a pair of electrode systems to analyze the electrochemical performances. Figure $4 \mathrm{a}$ presents the CV curves of the prepared samples at $1 \mathrm{mV} \mathrm{s}^{-1}$, in which the TAC electrode displayed a limited performance. In contrast, the CV curves from the TAC2, TAC3, and TAC4 electrodes represent quasi-rectangle shapes, demonstrating ideal capacitive behavior. Notably, the optimized capacitance was achieved from the TAC3 electrode. Moreover, as shown in Figure 4b, TAC3 retains an initial performance trend even at a high scan rate of $30 \mathrm{mV} \mathrm{s}^{-1}$, manifesting outstanding reversibility. Figure 4c illustrates the GCD curves of the tested samples at $0.05 \mathrm{~A} \mathrm{~g}^{-1}$, where the as-prepared TAC electrode only shows an evident initial voltage loss (i.e., IR drop). Meanwhile, the linear and nearly symmetric charge/discharge curves for the TAC2, TAC3, and TAC4 electrodes were collected without an obvious IR drop. Compared to other electrodes, the TAC3 electrode shows the longest discharge times that agreed well with the CV measurements. Within the specific survey of the GCD curves for the TAC2, TAC3, and TAC4 electrodes at various current densities, we found that the linear and symmetrical curves are also retained even at $2.5 \mathrm{~A} \mathrm{~g}^{-1}$, as shown in Figure $4 \mathrm{~d}-\mathrm{f}$. Table 2 summarizes each capacitance of the prepared electrodes at the different current densities from 0.05 to $2.5 \mathrm{~A} \mathrm{~g}^{-1}$. The specific capacitance of TAC3 at $0.05 \mathrm{~A} \mathrm{~g}^{-1}$ reaches $256 \mathrm{~F} \mathrm{~g} \mathrm{~g}^{-1}$, holding a high capacitance $\left(221 \mathrm{~F} \mathrm{~g}^{-1}\right)$ even at $2.5 \mathrm{~A} \mathrm{~g}^{-1}(\sim 86.3 \%$ of the initial capacitance), whereas the TAC2 and TAC4 exhibit only $\sim 79.8 \%$ and $66.9 \%$ capacitance retention, respectively. Obviously, the TAC3 electrode showed an excellent rate performance and high capacitance retention, which are crucial for high-performance supercapacitors. Additionally, long-term cyclic stability is an important parameter in investigating the electrochemical performances of supercapacitors. As measured in Figure 4e, the TAC3 maintains $95.4 \%$ after 10,000 cycles at $50 \mathrm{~mA} \mathrm{~g}^{-1}$, indicating a stable cycling performance compared to the other TAC2 and TAC4 electrodes. Additionally, when scanning the leakage 
current of electrodes for each sample, as shown in Figure 4f, the curves were overlapped with the values of $0.022,0.014$, and $0.031 \mathrm{~mA}$ for TAC2, TAC3, and TAC4 electrodes, respectively. The lowest leakage current value in the TAC3 electrode means the highest stability among the other samples and is important for practical applications as small as possible. Furthermore, the specific capacitance of TAC3 is compared with those of teawaste-based carbon materials and other porous carbon materials, as listed in Table 3. It is noteworthy to mention that the competitive capacitance of TAC3 indicates that tea waste is a potential candidate as the electrode for high-performance supercapacitors.
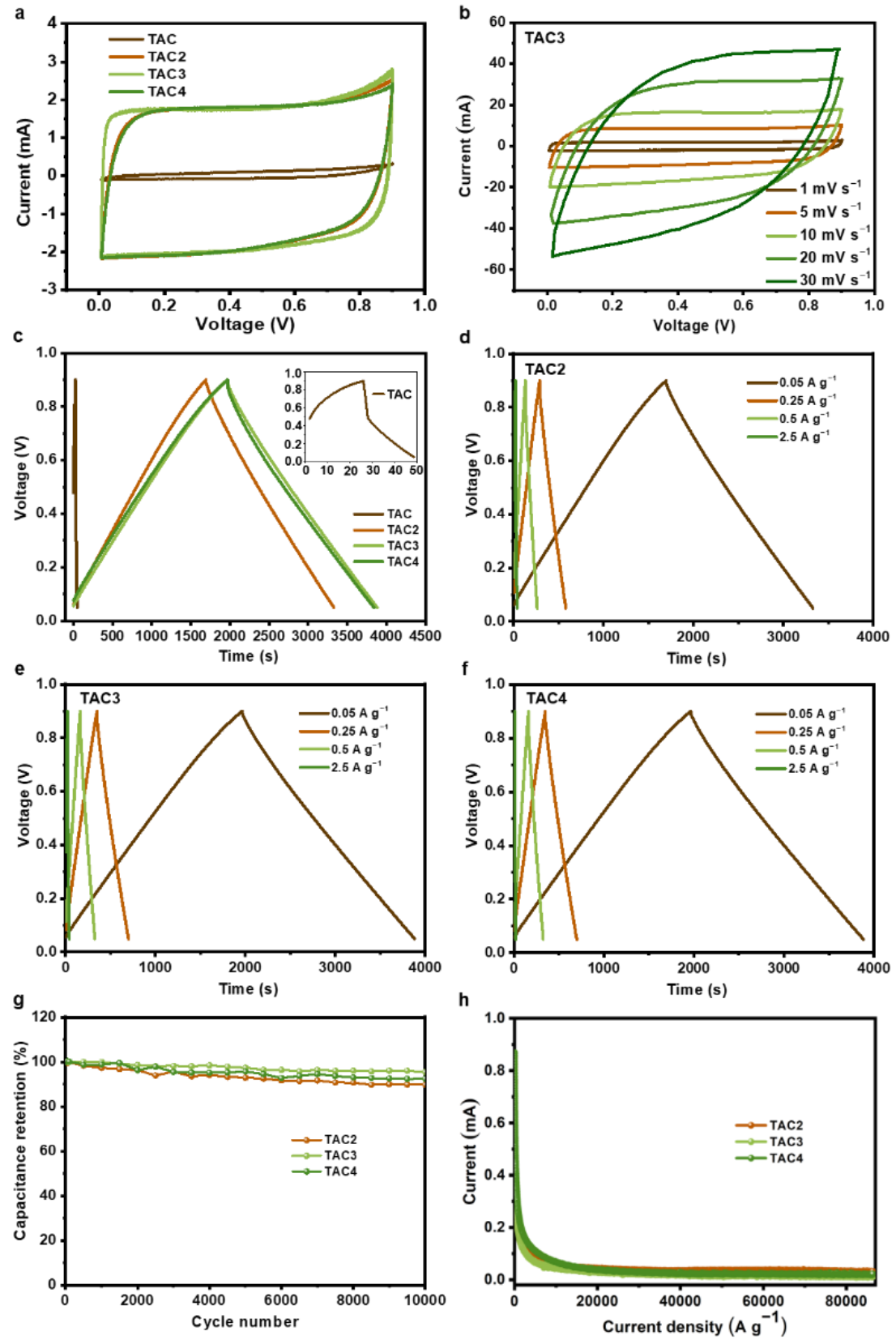

Figure 4. CV curves of the as-prepared samples at the scan rate of $1 \mathrm{mV} \mathrm{s}^{-1}$ (a); CV curves of TAC3 at different scan rates (b); GCD curves of all the samples at $0.05 \mathrm{~A} \mathrm{~g}^{-1}$ (c); GCD curves of TAC2 (d), TAC3 (e), and TAC4 (f) at different current densities; cycling performance under 1000 cycles of tea-waste-based activated carbons (g); and the leakage current curves of tea-waste-based activated carbons (h). 
Table 2. The specific capacitances of the activated carbons at different current densities.

\begin{tabular}{|c|c|c|c|c|c|}
\hline \multirow{2}{*}{ Samples } & \multicolumn{4}{|c|}{ Specific Capacitance $\left(\mathrm{F} \mathrm{g}^{-1}\right)$} & \multirow{2}{*}{$\begin{array}{l}\text { Capacitance } \\
\text { Retention * }\end{array}$} \\
\hline & $0.05 \mathrm{~A} \mathrm{~g}^{-1}$ & $0.25 \mathrm{~A} \mathrm{~g}^{-1}$ & $0.5 \mathrm{~A} \mathrm{~g}^{-1}$ & $2.5 \mathrm{~A} \mathrm{~g}^{-1}$ & \\
\hline TAC & 5 & - & - & - & - \\
\hline TAC2 & 218 & 201 & 193 & 174 & $79.8 \%$ \\
\hline TAC3 & 256 & 238 & 232 & 221 & $86.3 \%$ \\
\hline TAC4 & 242 & 201 & 200 & 162 & $66.9 \%$ \\
\hline
\end{tabular}

Table 3. The specific capacitances of the as-prepared carbon compared with those of the tea-wastebased carbon materials and other porous carbon materials.

\begin{tabular}{|c|c|c|c|}
\hline Active Materials & $\begin{array}{l}\text { Current } \\
\text { Density } \\
\left(\mathrm{A} \mathrm{g}^{-1}\right)\end{array}$ & $\begin{array}{c}\text { Specific } \\
\text { Capacitance } \\
\left(\mathrm{F} \mathrm{g}^{-1}\right)\end{array}$ & References \\
\hline tea factory waste & 2 & 155 & [12] \\
\hline $\begin{array}{l}\text { green tea waste-derived ultrathin mesoporous } \\
\text { graphitic carbon nanoflakes }\end{array}$ & 0.5 & 162 & {$[26]$} \\
\hline tea-waste-based activated carbon & 0.1 & 140 & [27] \\
\hline tea-waste-based, multi-hierarchical porous carbon & 1 & 291.2 & [56] \\
\hline $\begin{array}{l}\text { microporous and mesoporous activated carbons } \\
\text { produced from tea waste }\end{array}$ & $1.5 \mathrm{~mA} \mathrm{~cm}^{2}$ & 203 & [28] \\
\hline activated carbons derived from tea leaf waste & 1 & 330 & [24] \\
\hline $\begin{array}{l}\text { hierarchical porous carbon with multi-heteroatom } \\
\text { co-doping from tea waste }\end{array}$ & 0.5 & 170 & [57] \\
\hline activated biomass carbon from tea leaves & 0.5 & 131.95 & [58] \\
\hline $\begin{array}{l}\text { hierarchically porous carbon nanosheets from } \\
\text { coffee grounds waste }\end{array}$ & 0.5 & 129 & [59] \\
\hline biowaste lemon-peel-derived carbon & 0.2 & 106 & [20] \\
\hline sesame husk-based activated carbon & 2.5 & 235 & [19] \\
\hline $\begin{array}{l}\mathrm{MnO}_{\mathrm{X}} \text {-modified corrugated carton-derived } \\
\text { hierarchical porous carbon }\end{array}$ & 2.5 & 279 & [17] \\
\hline $\begin{array}{l}\text { activated carbon derived from anaerobic } \\
\text { digester residues }\end{array}$ & 1 & 184 & [48] \\
\hline $\begin{array}{l}\text { hierarchical N-doped porous carbon nanosheet } \\
\text { material from soybean milk }\end{array}$ & 0.5 & 149 & [26] \\
\hline $\begin{array}{l}\text { heteroatom-doped porous carbon sheets derived } \\
\text { from protein-rich wheat gluten }\end{array}$ & 0.5 & 350 & [60] \\
\hline activated carbon derived from rotten carrot & $10 \mathrm{mHz}$ & 135.5 & [61] \\
\hline porous carbons derived from tea waste & 2.5 & 221 & This work \\
\hline
\end{tabular}

As presented in Figure 5, we fabricated a coin-cell-type supercapacitor for a viable format to understand the charging/discharging process of the symmetric supercapacitors; the actual digital image of the coin cell shows a basic structure, and a schematic illustrates the charging/discharging process of the symmetric supercapacitors. In our experimental scheme, by designing the interconnected pores in the structured electrode, we postulate that the fluently transferred charges can be expected, and the ions can be freely diffused in the electrolyte. Based on the optimized condition for the supercapacitor electrode (i.e., TAC3), the excellent electrochemical performances can be attributed to the following reasons. Firstly, the TAC3 electrode yielded a high surface area with a value of $2235 \mathrm{~m}^{2} \mathrm{~g}^{-1}$, providing rich active sites and bringing a relatively large capacity during the charging/discharging process. Second, copious oxygen-containing functional groups at the surface of TAC3 were derived during the manufacturing process, exhibiting hydrophilicity and wettability, which is advantageous in contact conditions where electrolyte ions are easily accessible with the porous electrode. This characteristic feature in surface chemistry results in enhanced electrochemical performances. Furthermore, the interconnected frameworks in the porous electrode offer the intrinsic passways rapid ion diffusion and charge transfer, promoting cycling stability and reversibility. Within this combinatorial condition, our experimental results demonstrate an outstanding electrochemical performance of the tea-waste-based electrodes. Thus, we believe that our present study may provide an extremely simple hydrothermal method in designing practical electrode materials for 
supercapacitor applications by utilizing low-cost and eco-friendly biowastes as the raw materials combined with $\mathrm{KOH}$ activation.

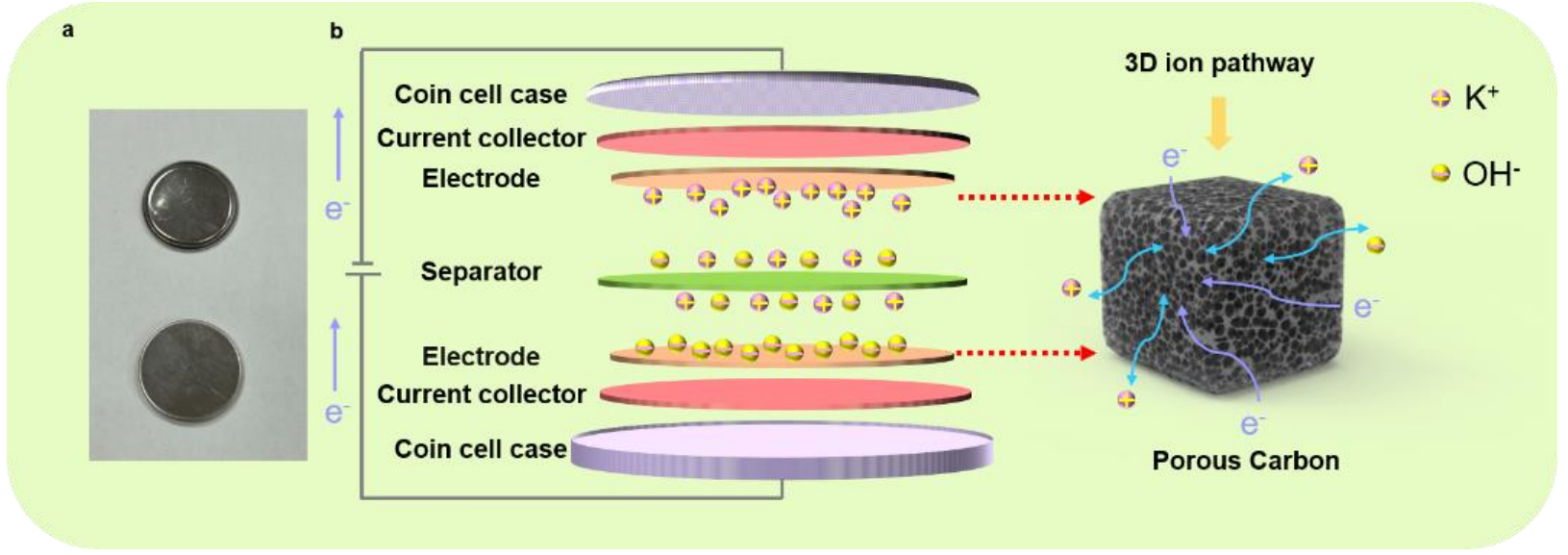

Figure 5. Digital image of the coin cell (a) and the schematic of the charging/discharging process of the symmetric supercapacitor $(\mathbf{b})$.

\section{Conclusions}

In summary, we developed a simple process to produce porous carbons derived from tea waste using hydrothermal treatment with $\mathrm{KOH}$ activation. During the process, $\mathrm{KOH}$, as an activating agent, reacts with carbon to create and expand pores. In this work, we found that the amount of $\mathrm{KOH}$ has a crucial impact on the microstructure and electrochemical performances. Among the porous carbons, TAC3, with an interconnected framework, presents the highest specific surface area of $2235 \mathrm{~cm}^{3} \mathrm{~g}^{-1}$ and high hydrophilicity. When used as the electrode for the supercapacitor, TAC3 delivers an excellent specific capacitance $\left(256 \mathrm{~F} \mathrm{~g}^{-1}\right)$ at $0.05 \mathrm{~A} \mathrm{~g}^{-1}$ and retains $221 \mathrm{~F} \mathrm{~g}^{-1}$ at $2.5 \mathrm{~A} \mathrm{~g}^{-1}$. Meanwhile, the capacitance maintains $95.4 \%$ after 10,000 cycles, and the leakage current is only $0.014 \mathrm{~mA}$. These results demonstrate that tea waste is a promising candidate to synthesize electrode materials for high-performance supercapacitors. Our work provides an effective and feasible approach to recycling eco-friendly and low-cost biowastes and increasing value-added utilization in the field of energy storage, which is fitted with the demands of reducing pollution and carbon emissions $[62,63]$.

Author Contributions: Conceptualization, X.Q., S.W.H. and C.Z.; methodology, X.Q. and W.K.; software, W.K. and C.L.; validation, X.Q., C.Z. and S.W.H.; formal analysis, X.Q.; investigation, X.Q.; resources, C.Z. and S.W.H.; data curation, C.Z. and S.W.H.; writing-original draft preparation, X.Q.; writing-review and editing, S.W.H.; visualization, S.W.H. and C.L.; supervision, C.Z.; project administration, S.W.H.; funding acquisition, C.Z. and S.W.H. All authors have read and agreed to the published version of the manuscript.

Funding: This research was funded by the National Research Foundation (NRF) of Korea under the auspices of the Ministry of Science and ICT, Republic of Korea (NRF-2021R1A5A1032937, NRF-2020R1F1A1077033).

Institutional Review Board Statement: Not applicable.

Informed Consent Statement: Not applicable.

Data Availability Statement: The data presented in this study are available on request from the corresponding authors.

Conflicts of Interest: The authors declare no conflict of interest. 


\section{References}

1. Chatterjee, D.P.; Nandi, A.K. A review on the recent advances in hybrid supercapacitors. J. Mater Chem. A 2021, 9, 15880-15918. [CrossRef]

2. Lai, C.; Cheng, L.; Sun, Y.; Lee, K.; Lin, B. Alkaline aqueous rechargeable Ni-Fe batteries with high-performance based on flower-like hierarchical $\mathrm{NiCo}_{2} \mathrm{O}_{4}$ microspheres and vines-grapes-like $\mathrm{Fe}_{3} \mathrm{O}_{4}$-NGC composites. Appl. Surf. Sci. 2021,563 , 150411. [CrossRef]

3. Lai, C.; Sun, Y.; Zhang, X.; Yang, H.; Kang, W.; Lin, B. Advanced flower-like $\mathrm{Co}_{3} \mathrm{O}_{4}$ with ultrathin nanosheets and 3D rGO aerogels as double ion-buffering reservoirs for asymmetric supercapacitors. Electrochim. Acta 2018, 271, 379-387. [CrossRef]

4. Qu, X.; Liu, Y.; Li, B.; Xing, B.; Huang, G.; Zhang, C.; Hong, S.W.; Yu, J.; Cao, Y. Synthesis of High Reversibility Anode Composite Materials Using $\mathrm{T}_{-} \mathrm{Nb}_{2} \mathrm{O}_{5}$ and Coal-Based Graphite for Lithium-Ion Battery Applications. Energ. Fuel 2020, 34, 3887-3894. [CrossRef]

5. Qu, X.; Liu, Y.; Li, B.; Xing, B.; Huang, G.; Zhao, H.; Jiang, Z.; Zhang, C.; Hong, S.W.; Cao, Y. Nanostructured T-Nb $2 \mathrm{O}_{5}$-based composite with reduced graphene oxide for improved performance lithium-ion battery anode. J. Mater Sci. 2020, 55, 13062-13074. [CrossRef]

6. Qu, X.; Xing, B.; Huang, G.; Zhao, H.; Jiang, Z.; Zhang, C.; Hong, S.W.; Cao, Y. Facile synthesis of flower-like T-Nb ${ }_{2} \mathrm{O}_{5}$ nanostructures as anode materials for lithium-ion battery. J. Mater Sci. Mater El 2020, 32, 875-885. [CrossRef]

7. Jiang, Z.; Zhang, C.; Qu, X.; Xing, B.; Huang, G.; Xu, B.; Shi, C.; Kang, W.; Yu, J.; Hong, S.W. Humic acid resin-based amorphous porous carbon as high rate and cycle performance anode for sodium-ion batteries. Electrochim. Acta 2021, 372, 137850. [CrossRef]

8. Wang, C.; Yang, D.; Qiu, X.; Zhang, W. Applications of Lignin-derived Porous Carbons for Electrochemical Energy Storage. Prog. Chem. 2020, 210116. [CrossRef]

9. Lai, C.; Sun, Y.; Zhang, X.; Yang, H.; Lin, B. High-performance double ion-buffering reservoirs of asymmetric supercapacitors based on flower-like $\mathrm{Co}_{3} \mathrm{O}_{4}$-G $>$ N-PEGm microspheres and 3D rGO-CNT>N-PEGm aerogels. Nanoscale 2018, 10, 17293-17303 [CrossRef]

10. Liu, Y.; Qu, X.; Huang, G.; Xing, B.; Fan, Y.; Zhang, C.; Cao, Y. Microporous carbon derived from anthracite as supercapacitor electrodes with commercial level mass loading. J. Energy Storage 2021, 43, 103200. [CrossRef]

11. Chen, T.; Luo, L.; Luo, L.; Deng, J.; Wu, X.; Fan, M.; Du, G.; Weigang, Z. High energy density supercapacitors with hierarchical nitrogen-doped porous carbon as active material obtained from bio-waste. Renew. Energ. 2021, 175, 760-769. [CrossRef]

12. Özarslan, S.; Raşit Atelge, M.; Kaya, M.; Ünalan, S. A Novel Tea factory waste metal-free catalyst as promising supercapacitor electrode for hydrogen production and energy storage: A dual functional material. Fuel 2021, 305, 121578. [CrossRef]

13. Mohamed, M.G.; Atayde, E.C.; Matsagar, B.M.; Na, J.; Yamauchi, Y.; Wu, K.C.W.; Kuo, S.-W. Construction Hierarchically Mesoporous/Microporous Materials Based on Block Copolymer and Covalent Organic Framework. J. Taiwan Inst. Chem. E 2020, 112, 180-192. [CrossRef]

14. Suárez, L.; Centeno, T.A. Unravelling the volumetric performance of activated carbons from biomass wastes in supercapacitors J. Power Sources 2020, 448, 227413. [CrossRef]

15. Talreja, N.; Jung, S.; Yen, L.T.H.; Kim, T. Phenol-formaldehyde-resin-based activated carbons with controlled pore size distribution for high-performance supercapacitors. Chem. Eng. J. 2020, 379, 122332. [CrossRef]

16. Usha Rani, M.; Nanaji, K.; Rao, T.N.; Deshpande, A.S. Corn husk derived activated carbon with enhanced electrochemical performance for high-voltage supercapacitors. J. Power Sources 2020, 471, 228387. [CrossRef]

17. Zhao, H.; Xing, B.; Zhang, C.; Huang, G.; Yu, J.; Jiang, Z.; Qu, X.; Wu, X.; Cao, Y.; Zhang, C. MnOX-modified corrugated carton-derived hierarchical porous carbon with ultrafast kinetics behaviour for high-performance symmetric supercapacitors J. Alloy Compd. 2020, 848, 156423. [CrossRef]

18. Liu, Y.; Qu, X.; Huang, G.; Xing, B.; Zhang, F.; Li, B.; Zhang, C.; Cao, Y. 3-Dimensional Porous Carbon with High Nitrogen Content Obtained from Longan Shell and Its Excellent Performance for Aqueous and All-Solid-State Supercapacitors. Nanomaterials 2020, 10, 808. [CrossRef]

19. Qu, X.; Liu, Y.; Zhang, C.; Zhu, A.; Wang, T.; Tian, Y.; Yu, J.; Xing, B.; Huang, G.; Cao, Y. Effect of different pretreatment methods on sesame husk-based activated carbon for supercapacitors with aqueous and organic electrolytes. J. Mater Sci. Mater El 2019, 30 , 7873-7882. [CrossRef]

20. Mehare, M.D.; Deshmukh, A.D.; Dhoble, S.J. Bio-waste lemon peel derived carbon based electrode in perspect of supercapacitor. J. Mater Sci. Mater El 2021, 32, 14057-14071. [CrossRef]

21. Shang, T.; Xu, Y.; Li, P.; Han, J.; Wu, Z.; Tao, Y.; Yang, Q.-H. A bio-derived sheet-like porous carbon with thin-layer pore walls for ultrahigh-power supercapacitors. Nano Energy 2020, 70, 104531. [CrossRef]

22. Mondal, M.; Goswami, D.K.; Bhattacharyya, T.K. Lignocellulose based Bio-waste Materials derived Activated Porous Carbon as Superior Electrode Materials for High-Performance Supercapacitor. J. Energy Storage 2021, 34, 102229. [CrossRef]

23. Tobi, A.R.; Dennis, J.O. Activated carbon from composite of palm bio-waste as electrode material for solid-state electric double layer capacitor. J. Energy Storage 2021, 42, 103087. [CrossRef]

24. Peng, C.; Yan, X.-B.; Wang, R.-T.; Lang, J.-W.; Ou, Y.-J.; Xue, Q.-J. Promising activated carbons derived from waste tea-leaves and their application in high performance supercapacitors electrodes. Electrochim. Acta 2013, 87, 401-408. [CrossRef] 
25. Khan, A.; Senthil, R.A.; Pan, J.; Osman, S.; Sun, Y.; Shu, X. A new biomass derived rod-like porous carbon from tea-waste as inexpensive and sustainable energy material for advanced supercapacitor application. Electrochim. Acta 2020, $335,135588$. [CrossRef]

26. Sankar, S.; Ahmed, A.T.A.; Inamdar, A.I.; Im, H.; Im, Y.B.; Lee, Y.; Kim, D.Y.; Lee, S. Biomass-derived ultrathin mesoporous graphitic carbon nanoflakes as stable electrode material for high-performance supercapacitors. Mater Des. 2019, 169, 107688. [CrossRef]

27. Gurten Inal, I.I.; Aktas, Z. Enhancing the performance of activated carbon based scalable supercapacitors by heat treatment. Appl. Surf. Sci. 2020, 514, 145895. [CrossRef]

28. Inal, I.I.G.; Holmes, S.M.; Banford, A.; Aktas, Z. The performance of supercapacitor electrodes developed from chemically activated carbon produced from waste tea. Appl. Surf. Sci. 2015, 357, 696-703. [CrossRef]

29. Long, C.; Chen, X.; Jiang, L.; Zhi, L.; Fan, Z. Porous layer-stacking carbon derived from in-built template in biomass for high volumetric performance supercapacitors. Nano Energy 2015, 12, 141-151. [CrossRef]

30. Wang, T.; Zhai, Y.; Zhu, Y.; Li, C.; Zeng, G. A review of the hydrothermal carbonization of biomass waste for hydrochar formation: Process conditions, fundamentals, and physicochemical properties. Renew. Sust. Energ. Rev. 2018, 90, 223-247. [CrossRef]

31. Hoekman, S.K.; Broch, A.; Robbins, C. Hydrothermal Carbonization (HTC) of Lignocellulosic Biomass. Energ. Fuel 2011, 25, 1802-1810. [CrossRef]

32. Kang, W.; Lin, B.; Huang, G.; Zhang, C.; Yao, Y.; Hou, W.; Xu, B.; Xing, B. Peanut bran derived hierarchical porous carbon for supercapacitor. J. Mater Sci. Mater El 2018, 29, 6361-6368. [CrossRef]

33. Li, M.; Cao, S.; Meng, X.; Studer, M.; Wyman, C.E.; Ragauskas, A.J.; Pu, Y. The effect of liquid hot water pretreatment on the chemical-structural alteration and the reduced recalcitrance in poplar. Biotechnol. Biofuels 2017, 10, 237. [CrossRef] [PubMed]

34. Liu, J.; Sun, N.; Sun, C.; Liu, H.; Snape, C.; Li, K.; Wei, W.; Sun, Y. Spherical potassium intercalated activated carbon beads for pulverised fuel $\mathrm{CO}_{2}$ post-combustion capture. Carbon 2015, 94, 243-255. [CrossRef]

35. Xu, Z.; Wu, M.; Chen, Z.; Chen, C.; Yang, J.; Feng, T.; Paek, E.; Mitlin, D. Direct Structure-Performance Comparison of All-Carbon Potassium and Sodium Ion Capacitors. Adv. Sci. 2019, 6, 1802272. [CrossRef] [PubMed]

36. Qu, X.; Huang, G.; Xing, B.; Si, D.; Xu, B.; Chen, Z.; Zhang, C.; Cao, Y. Core-shell carbon composite material as anode materials for lithium-ion batteries. J. Alloy Compd. 2019, 772, 814-822. [CrossRef]

37. Guo, M.; Guo, J.; Tong, F.; Jia, D.; Jia, W.; Wu, J.; Wang, L.; Sun, Z. Hierarchical porous carbon spheres constructed from coal as electrode materials for high performance supercapacitors. RSC Adv. 2017, 7, 45363-45368. [CrossRef]

38. Khoshbouy, R.; Takahashi, F.; Yoshikawa, K. Preparation of high surface area sludge-based activated hydrochar via hydrothermal carbonization and application in the removal of basic dye. Environ. Res. 2019, 175, 457-467. [CrossRef]

39. Zheng, H.; Sun, Q.; Li, Y.; Du, Q. Biosorbents prepared from pomelo peel by hydrothermal technique and its adsorption properties for congo red. Mater Res. Express 2020, 7, 045505. [CrossRef]

40. Gao, Y.; Yue, Q.; Gao, B.; Li, A. Insight into activated carbon from different kinds of chemical activating agents: A review. Sci. Total Environ. 2020, 746, 141094. [CrossRef]

41. Chun, S.-E.; Whitacre, J.F. Formation of micro/mesopores during chemical activation in tailor-made nongraphitic carbons Micropor Mesopor Mat. 2017, 251, 34-41. [CrossRef]

42. Rehman, A.; Park, S.J. Microporous carbons derived from melamine and isophthalaldehyde: One-pot condensation and activation in a molten salt medium for efficient gas adsorption. Sci. Rep. 2018, 8, 6092. [CrossRef] [PubMed]

43. Feng, H.; Hu, H.; Dong, H.; Xiao, Y.; Cai, Y.; Lei, B.; Liu, Y.; Zheng, M. Hierarchical structured carbon derived from bagasse wastes: A simple and efficient synthesis route and its improved electrochemical properties for high-performance supercapacitors J. Power Sources 2016, 302, 164-173. [CrossRef]

44. Hossain, M.D.; Zhang, Q.; Cheng, T.; Goddard, W.A.; Luo, Z. Graphitization of low-density amorphous carbon for electrocatalysis electrodes from ReaxFF reactive dynamics. Carbon 2021, 183, 940-947. [CrossRef]

45. Wang, D.; Geng, Z.; Li, B.; Zhang, C. High performance electrode materials for electric double-layer capacitors based on biomass-derived activated carbons. Electrochim. Acta 2015, 173, 377-384. [CrossRef]

46. Mohamed, M.G.; Ahmed, M.M.M.; Du, W.T.; Kuo, S.W. Meso/Microporous Carbons from Conjugated Hyper-Crosslinked Polymers Based on Tetraphenylethene for High-Performance $\mathrm{CO}_{2}$ Capture and Supercapacitor. Molecules 2021, 26, 738. [CrossRef]

47. Ma, Y. Comparison of Activated Carbons Prepared from Wheat Straw via $\mathrm{ZnCl}_{2}$ and $\mathrm{KOH}$ Activation. Waste Biomass Valor 2016, 8, 549-559. [CrossRef]

48. Wang, C.; Wang, J.; Wu, W.; Qian, J.; Song, S.; Yue, Z. Feasibility of activated carbon derived from anaerobic digester residues for supercapacitors. J. Power Sources 2019, 412, 683-688. [CrossRef]

49. Lota, G.; Krawczyk, P.; Lota, K.; Sierczyńska, A.; Kolanowski, Ł.; Baraniak, M.; Buchwald, T. The application of activated carbon modified by ozone treatment for energy storage. J. Solid State Electrochem. 2016, 20, 2857-2864. [CrossRef]

50. Huber, L.; Hauser, S.B.; Brendlé, E.; Ruch, P.; Ammann, J.; Hauert, R.; Widmer, R.N.; Ubert, C.J.; Matam, S.K.; Yoon, S.; et al. The effect of activation time on water sorption behavior of nitrogen-doped, physically activated, monolithic carbon for adsorption cooling. Micropor. Mesopor. Mat. 2019, 276, 239-250. [CrossRef]

51. Gorgulho, H.F.; Gonçalves, F.; Pereira, M.F.R.; Figueiredo, J.L. Synthesis and characterization of nitrogen-doped carbon xerogels. Carbon 2009, 47, 2032-2039. [CrossRef] 
52. Peng, Y.; Chen, Z.; Zhang, R.; Zhou, W.; Gao, P.; Wu, J.; Liu, H.; Liu, J.; Hu, A.; Chen, X. Oxygen-Containing Functional Groups Regulating the Carbon/Electrolyte Interfacial Properties Toward Enhanced $\mathrm{K}^{+}$Storage. Nanomicro. Lett. 2021, 13, 192. [CrossRef] [PubMed]

53. He, Y.; Zhang, Y.; Li, X.; Lv, Z.; Wang, X.; Liu, Z.; Huang, X. Capacitive mechanism of oxygen functional groups on carbon surface in supercapacitors. Electrochim. Acta 2018, 282, 618-625. [CrossRef]

54. Han, L.; Chen, X.; Zeng, S.; Liu, J.; Yang, Z.; Wang, Z.; Li, L.; Wang, H.; Hou, Z.; Xu, M. B, N Dual Doped Coral-Like Carbon Framework With Superior Pseudocapacitance and Surface Wettability. Front Mater 2021, 8, 705930. [CrossRef]

55. Ilnicka, A.; Skorupska, M.; Szkoda, M.; Zarach, Z.; Kamedulski, P.; Zielinski, W.; Lukaszewicz, J.P. Combined effect of nitrogendoped functional groups and porosity of porous carbons on electrochemical performance of supercapacitors. Sci. Rep. 2021, 11, 18387. [CrossRef] [PubMed]

56. Fu, M.; Huang, J.; Feng, S.; Zhang, T.; Qian, P.-C.; Wong, W.-Y. One-step solid-state pyrolysis of bio-wastes to synthesize multi-hierarchical porous carbon for ultra-long life supercapacitors. Mater Chem. Front 2021, 5, 2320-2327. [CrossRef]

57. Ma, Q.; Xi, H.; Cui, F.; Zhang, J.; Chen, P.; Cui, T. Self-templating synthesis of hierarchical porous carbon with multi-heteroatom co-doping from tea waste for high-performance supercapacitor. J. Energy Storage 2022, 45, 103509. [CrossRef]

58. Thirumal, V.; Yuvakkumar, R.; Ravi, G.; Dineshkumar, G.; Ganesan, M.; Alotaibi, S.H.; Velauthapillai, D. Characterization of activated biomass carbon from tea leaf for supercapacitor applications. Chemosphere 2021, 291, 132931. [CrossRef]

59. Yun, Y.S.; Park, M.H.; Hong, S.J.; Lee, M.E.; Park, Y.W.; Jin, H.J. Hierarchically porous carbon nanosheets from waste coffee grounds for supercapacitors. ACS Appl. Mater Interfaces 2015, 7, 3684-3690. [CrossRef]

60. Xu, S.-W.; Zhao, Y.-Q.; Xu, Y.-X.; Chen, Q.-H.; Zhang, G.-Q.; Xu, Q.-Q.; Zhao, D.-D.; Zhang, X.; Xu, C.-L. Heteroatom doped porous carbon sheets derived from protein-rich wheat gluten for supercapacitors: The synergistic effect of pore properties and heteroatom on the electrochemical performance in different electrolytes. J. Power Sources 2018, 401, 375-385. [CrossRef]

61. Ahmed, S.; Ahmed, A.; Rafat, M. Supercapacitor performance of activated carbon derived from rotten carrot in aqueous, organic and ionic liquid based electrolytes. J. Saudi Chem. Soc. 2018, 22, 993-1002. [CrossRef]

62. Zhai, M.; Huang, G.; Liu, L.; Zheng, B.; Li, Y. Economic modeling of national energy, water and air pollution nexus in China under changing climate conditions. Renew. Energ. 2021, 170, 375-386. [CrossRef]

63. Yadav, D.; Kumari, R.; Kumar, N.; Sarkar, B. Reduction of waste and carbon emission through the selection of items with cross-price elasticity of demand to form a sustainable supply chain with preservation technology. J. Clean Prod. 2021, $297,126298$. [CrossRef] 